\title{
Prevalence of Hepatitis B, C, and D among Thalassemia patients in Sulaimani Governorate
}

\author{
Salih Ahmed Hama \\ University of Sulaimani, College of Science, Biology Dept, \\ Komar University for Science \& Technology, MLS Dept, \\ University of Human Development, College of Science \\ salih.hama@univsul.edu.iq; \\ salih.hama@kust.edu.iq; salih.hama@uhd.edi.iq
}

\author{
Moaid Ibrahim Sawa \\ College of Pharmacy, \\ Hawler Medical University \\ drsawa@yahoo.com
}

\begin{abstract}
Infectious diseases are the leading cause of mortality worldwide, with hepatitis viruses in particular making global impact on socioeconomic development and this infection remains a serious public health issue. This study was performed to investigate the prevalence of Hepatitis $B, C$ and $D$ among multitransfused risk groups in Sulaimani Governorate, 120 major thalassemic patients were tested by serological and enzyme-linked immunosorbent assay (ELISA) technique and Recombinant ImmunoBlot Assay (RIBA) test was done as a confirmatory test for all HCV ELISA positive patients. It was observed that the prevalence of $\mathrm{HCV}$ was higher (29.1\%) comparing to $\mathrm{HBV}(22.5 \%)$ and $\mathrm{HDV}(3.3 \%)$. The prevalence of $\mathrm{HCV}-\mathrm{HBV}$ coinfection was (5\%), HCV-HBV-HDV coinfections were $(0.83 \%)$. Statistical analysis showed that the age was significantly effective on the prevalence of $\mathrm{HBV}(p=0.009)$, parenteral medication users showed a significant relation with $\mathrm{HBV}$ and $\mathrm{HCV}$ prevalence $(p=0.03$ and 0.041$)$ respectively. The blood transfusion frequency was significantly related to $\mathrm{HBV}$ and $\mathrm{HCV}$ prevalence $(p=0.042$ and 0.035$)$ respectively. It was noticed that vaccination significantly related to $\mathrm{HBV}$ prevalence among thalassemic patients $(p=0.002)$.
\end{abstract}

Keywords: HCV, HBV, HDV, ELISA, Co-infection, Thalassemia

\section{INTRODUCTION}

Hepatitis is an inflammation of the liver and is a major public health problem worldwide; it can cause considerable morbidity and mortality among the human population from acute to chronic infections expressed as acute and chronic hepatitis, cirrhosis and hepatocarcinoma [1]. At least, five viral etiological agents alphabetically named $\mathrm{A}, \mathrm{B}, \mathrm{C}, \mathrm{D}$, and $\mathrm{E}$ have definitely been recognized, in addition to $F$ and $G$ which have also been described [2].

Hepatitis B virus is a small enveloped virus, hepatotropic, with a partly double-stranded, circular DNA genome [3, 4], a member of the Hepadnaviridae family, which is a major cause of acute and chronic hepatitis, cirrhosis, and hepatocellular carcinoma. More than 2000 million people have been infected with this virus; about 350 millions of whom remain infected chronically and become carriers of the virus [5, 6]. Hepatitis $\mathrm{C}$ is a small, enveloped, positive stranded RNA virus and is a member of Flaviviridae family [7, 8, 9]. It can result in acute or chronic hepatitis, 170 million chronic carriers worldwide are present $[10,11]$.

It is highly mutable due to lacking proof-reading activity $[12,13]$. Hepatitis delta virus is a defective and negative sense single-stranded circular RNA virus [14, 15]. It requires hepatitis $B$ surface antigen ( $\mathrm{HBsAg}$ ) for packaging and transmission, and always coexists with hepatitis B virus (HBV) in natural infections $[16,17]$.

It is roughly spherical, enveloped, without distinct nucleocapsid structure $[18,19]$. HDV was shown to be associated with the most severe forms of acute and chronic hepatitis in many HBsAg-positive patients and present worldwide in all age groups [20] with a high prevalence in different countries [11].

Multitransfused thalassemia patients are a population at high risk for blood-borne viral infections, especially for HBV and HCV which can cause post transfusion hepatitis [21]. The reported frequency of infection varies significantly for different countries, due to different prevalence and sensitivity of the diagnostic methods [22].

It was proved that the blood transfusion is a common transmission pathway of blood-borne viral hepatitis among thalassemia patients who continuously receive blood due to their disease type [23]. This study was aimed to investigate the prevalence $\mathrm{HBV}, \mathrm{HCV}$, and HDV among thalassemia patients in Sulaimani.

\section{MATERIALS AND METHODS}

Fresh venous blood was collected from 120 major thalassemia patients in Sulaimani Governorate Sulaimani Governorate which is located in the Iraqi Kurdistan Region from September 1, 2007, to August 1, 2008. Serum was separated and distributed to three parts and stored in deep freeze $\left(-80^{\circ} \mathrm{C}\right)$. ELISA technique was depended for detection of anti-HCV antibodies (Bioelisa HCV, Biokit, Co. Spain), HBs antigens (Bioelisa HBsAg, Biokit, Co. Spain) and anti-HDV antibodies (Bioelisa HDV, Biokit, Co. Spain).

For all ELISA positive HCV samples RIBA test (Ortho diagnostic, Raritan, New York) was done as a confirmatory test and RIBA negative samples were canceled. 
All laboratory tests and examinations were done in post graduate research laboratories in Biology department, central laboratory in Sulaimani, Hiwa Hospital laboratory, and central laboratory for disease analysis in Baghdad.

The obtained results were statistically analyzed using SPSS version 13, depending on regression and both chisquare test and t-test.

\section{RESULTS}

The total prevalence of HBV was $(22.5 \%)$, HCV (29.1\%), and HDV (3.3\%) among thalassemia patients (Table, 1). Depending on the three age groups, the highest HBV prevalence was with patients their age above 5 years $(32.3 \%)$, also $\mathrm{HCV}$ prevalence was highest among patients their age between 1-5 years $(35.2 \%)$.

HBV prevalence was $(24.7 \%)$ among patients with frequent medication uses, whereas $\mathrm{HCV}$ prevalence was higher among the same group (32.3\%) and concurrent infection with HBV-HCV was (5.7\%) (Fig. -1-). Analyzing the results statistically showed that the age significantly related to the prevalence of $\mathrm{HBV}(\mathrm{p}=$
0.009), also parenteral medication uses showed a significant relation with $\mathrm{HBV}$ and $\mathrm{HCV}$ prevalence $(\mathrm{p}=$ 0.03 and 0.041 ) respectively.

HBV prevalence was higher among thalassemia patients received blood once less than 1 month and was (35.1\%), whereas HCV prevalence was higher among the same group and was (43.2\%) and concurrent HBV$\mathrm{HCV}$ infection was $(6 \%)$ among patients who received blood once more than 1 month. HBV prevalence was $(24.27 \%)$ among patients with the previous history of surgical operations, while HCV prevalence was higher among the same group and was (32\%).

It was noticed that HBV prevalence was higher among non-vaccinated patients (31.5\%) (Fig. -2-).

Statistical analysis showed that blood transfusion significantly related to $\mathrm{HBV}$ and $\mathrm{HCV}$ prevalence $(\mathrm{p}=$ 0.042 and 0.035$)$ respectively. It was noticed that vaccination significantly related to $\mathrm{HBV}$ prevalence among thalassemia patients $(\mathrm{p}=0.002)$.

Table -1- Risk factors associated with HBV, HCV, HDV and concurrent infections among thalassemia patients in Sulaimani Governorate

\begin{tabular}{|c|c|c|c|c|c|c|c|}
\hline \multicolumn{2}{|c|}{ Risk factors } & \multirow{2}{*}{$\begin{array}{c}\text { Subject } \\
\text { No. }\end{array}$} & \multirow{2}{*}{$\begin{array}{c}\text { HBV } \\
\text { No (\%) }\end{array}$} & \multirow{2}{*}{$\begin{array}{c}\text { HBV-HDV } \\
\text { No }(\%)\end{array}$} & \multirow{2}{*}{$\begin{array}{c}\text { HCV } \\
\text { No (\%) }\end{array}$} & \multirow{2}{*}{$\begin{array}{c}\text { HBV-HCV } \\
\text { No }(\%)\end{array}$} & \multirow{2}{*}{$\begin{array}{c}\text { HBV-HCV- } \\
\text { HDV } \\
\text { No }(\%)\end{array}$} \\
\hline & & & & & & & \\
\hline \multirow{3}{*}{ Age (years) } & $<1$ & 21 & $2(9.5 \%)$ & $0(0.0 \%)$ & $5(23.8 \%)$ & $1(4.7 \%)$ & $0(0.0 \%)$ \\
\hline & $1-5$ & 34 & $4(11.7 \%)$ & $1(2.9 \%)$ & $12(35.2 \%)$ & $1(2.9 \%)$ & $0(0.0 \%)$ \\
\hline & $>5$ & 65 & $21(32.3 \%)$ & $3(4.6 \%)$ & $18(27.6 \%)$ & $4(6.1 \%)$ & $1(1.5 \%)$ \\
\hline \multirow{2}{*}{$\begin{array}{l}\text { Parenteral } \\
\text { medication }\end{array}$} & Yes & 105 & $26(24.7 \%)$ & $4(3.8 \%)$ & $34(32.3 \%)$ & $6(5.7 \%)$ & $1(0.09 \%)$ \\
\hline & No & 15 & $0(0.0 \%)$ & $0(0.0 \%)$ & $1(6.6 \%)$ & $0(0.0 \%)$ & $0(0.0 \%)$ \\
\hline \multirow{2}{*}{$\begin{array}{c}\text { Blood } \\
\text { transfusion } *\end{array}$} & $<1$ month & 37 & $13(35.1 \%)$ & $1(2.7 \%)$ & $16(43.2 \%)$ & $1(2.7 \%)$ & $0(0.0 \%)$ \\
\hline & $>1$ month & 83 & $14(20.4 \%)$ & $3(3.6 \%)$ & $19(27.7 \%)$ & $5(6 \%)$ & $1(1.2 \%)$ \\
\hline \multirow{2}{*}{$\begin{array}{c}\text { Past surgical } \\
\text { operation }\end{array}$} & Yes & 17 & $2(11.7 \%)$ & $0(0.0 \%)$ & $2(11.7 \%)$ & $0(0.0 \%)$ & $0(0.0 \%)$ \\
\hline & No & 103 & $25(24.27 \%)$ & $4(3.8 \%)$ & $33(32 \%)$ & $6(5.8 \%)$ & $1(0.09 \%)$ \\
\hline \multirow{2}{*}{ Vaccination } & Yes & 44 & $3(6.8 \%)$ & $0(0.0 \%)$ & & & \\
\hline & No & 76 & $24(31.5 \%)$ & $4(5.2 \%)$ & & & \\
\hline \multicolumn{2}{|c|}{ Total } & 120 & $27(22.5 \%)$ & $4(3.3 \%)$ & $35(29.1 \%)$ & $6(5 \%)$ & $1(0.008 \%)$ \\
\hline
\end{tabular}

\footnotetext{
* Depending on major and intermediate thalassemia.
} 




Figure-1- Prevalence of HBV, HCV, and HDV among thalassemia patients in Sulaimani Governorate

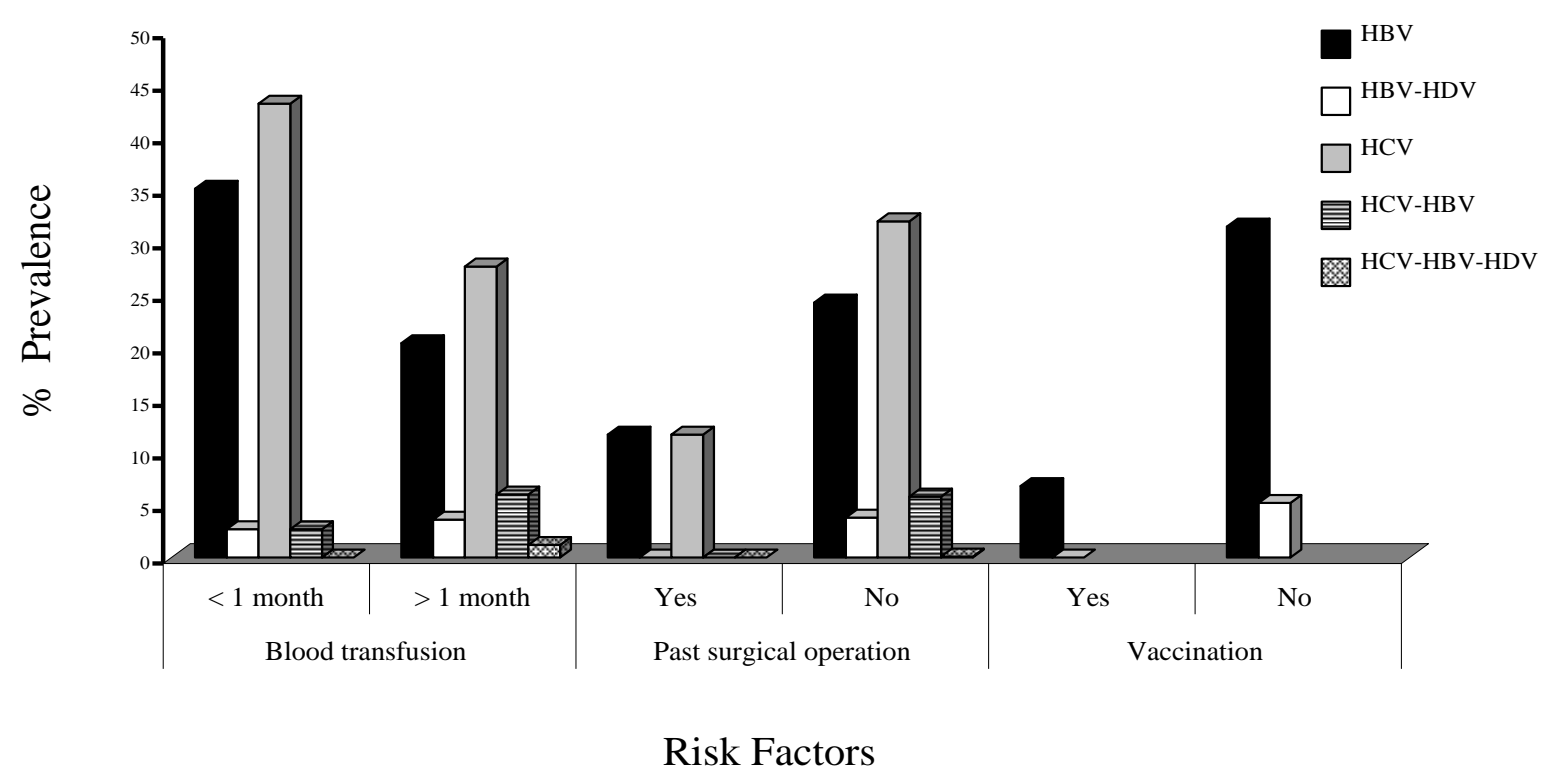

Figure-2- Risk factors related to the HBV, HCV and HDV prevalence among thalassemia patients.

\section{DISCUSSION}

Multi-transfused thalassemia patients are a population at high risk for blood-borne viral infections. Several factors could explain the high prevalence of $\mathrm{HBV}, \mathrm{HCV}$ and sometimes HDV among thalassemic patients, including frequent blood transfusion [23]. The vast majority of the cases may be due to the sensitivity of blood screening before transfusion [24], as it was clarified by different investigators that advances in screening for detection of blood-borne viruses have greatly diminished the risk of infection with blood transfusion in developing countries [25]. Moreover, parenteral medication may be another significant risk factor rather than transfusion [26]. It was observed that $\mathrm{HCV}$ prevalence was higher than HBV, which may be due to the availability of the HBV vaccine that can be effective in minimizing the prevalence of $\mathrm{HBV}$ infections, especially the current study confirmed the positive effects of vaccination. The current results were parallel to different previous studies [27, 28]. Moreover; the current observations agreed with past studies who showed that the prevalence of HCV was higher than that of HBV [29, 30].

From other reports, it was concluded that the frequency of HCV markers was $46.8 \%$ [31] which was higher than the results observed in the current study. Reports from Italy found that about $15 \%$ of thalassemia patients had been exposed to hepatitis $\mathrm{C}$ and the prevalence of this virus was significantly high [32]. Results of our study were in agreement with results obtained by others who recorded the higher prevalence of $\mathrm{HCV}$ than $\mathrm{HBV}$ among multitransfused thalassemia [33, 34], although 
others reported high $\mathrm{HBV}$ prevalence among multitransfused thalassemia patients [35, 36, 37]. Studies concluded that in countries with a high Human Development Index, the rate of new viral hepatitis infection in thalassemia patients has dropped markedly in recent years but this has not been the case in countries with a low-medium Human Development Index. Among the large majority of chronically-transfused patients living in underdeveloped or developing countries, HCV infection remains a significant problem for patients with thalassemia major [25]. In Iran [38] it was observed that the prevalence of $\mathrm{HCV}$ infection in thalassemia patients has decreased significantly. The results observed in this study were similar to observations reported by other investigators in relatively recent years. Costello with colleagues [39] observed that HCV is responsible for 80$90 \%$ of post transfusion hepatitis in patients who received blood transfusion. In a study done in Egypt [40].

It was found that HCV prevalence was higher than HBV prevalence with was parallel to the current results. Similarly, in Pakistan, it was found that HCV prevalence was higher than HBV among thalassemia patients [41]. Moreover, they found that the older patients were at a higher risk for infections with these viruses with is parallel to the current conclusions. The current results were agreed with recent observations reported by Khalil and co-workers in 2016 [42], who reported a higher prevalence of $\mathrm{HCV}$ than $\mathrm{HBV}$ among thalassemia patients. As it was clarified the prevalence of HBV was relatively low, otherwise the HDV cannot be found without $\mathrm{HBV}$, so the lowest prevalence of HDV infections can be explained by lower HBV infections as well as discussed, the HBV vaccination also may be behind the lowest HDV infection. Although there are no data about HDV infections in our hospitals and community, this is the first study on HDV in Kurdistan. Similar studies done among type II diabetic patients in Sulaimani city reported a lower prevalence of $\mathrm{HCV}$ infections [43].

\section{CONCLUSIONS}

From the current study the following points were concluded:

1. Thalassemic patients in Sulaimani Governorate are at a high risk for blood-borne viral hepatitis infections including HCV, HBV, and HDV.

2. The prevalence of $\mathrm{HCV}$ was higher in compare HBV and HDV.

3. The age (duration of blood transfusion), blood transfusion showed significant effects on the HCV and HBV seropositivity.

4. Vaccination was significantly effective on $\mathrm{HBV}$ seropositivity.

\section{REFERENCES}

1. Y. A. Johnsosn, J. Graeme, M. Alexander, A. Alfredo, "Viral hepatitis. Gut Supplement; pp. S47- S62, 1991.

2. A. J. Zuckerman. Alphabet of hepatitis viruses. Lancet; 347:558-9. 1996.

3. C. Seeger; W. S. Mason. Hepatitis B virus biology. Microbiol Mol Biol Rev; 64:51-68. 2000.

4. D. Ganem; A. M. Prince. Hepatitis B infection: natural history and clinical consequences. $N$ Engl $J$ Med; 350:1118-29. 2004.

5. J. E. Maynard; M. A. Kane; M. J. Alter; S. C. Hadler. Control of hepatitis B by immunization: global perspective. In: Zuckerman AJ, editor. Viral hepatitis and liver disease. New York: Alan R Liss Inc., pp. 967-9. 1988

6. F. B. Hollinger; T. J. Liang. Hepatitis B virus. In: Knipe D. M; Howley P. M; and editors. Fields Virology. $4^{\text {th }}$ edition. Philadelphia: Lippincott Williams and Wilkins; pp. 2971 -3036. 2001.

7. L. F. He; D. Alling; T. Popkin; M. Shapiro; H. J. Alter; R. H. Purcell. Determining the size of non-A, non-B hepatitis virus by filtration. J Infect Dis; 156 , 636-640. 1987.

8. K. Ohba; M. Mizokami; J. Y. Lau; E. Orito; K. Ikeo; T. Gojobori. Evolutionary relationship of hepatitis $\mathrm{C}$, pesti-, flavi-, plantviruses, and newly discovered GB hepatitis agents. FEBS Lett; 378, 232-234. 1996.

9. Y. K. Shimizu; S. M. Feinstone; M. Kohara; R. H. Purcell; H. Yoshikura. Hepatitis C virus: detection of intracellular virus particles by electron microscopy. Hepatology; 23 (2):205-9. 1996.

10. WHO. Weekly epidemiological record: World Health Organization. 1999.

11. S. H. Mehta; A. Cox; D. R. Hoover. Protection against persistence of hepatitis C. Lancet; 359: 1478-83. 2002.

12. G. Luo; S. Xin; Z. Cai. Role of the 5'-proximal stem-loop structure of the 5' untranslated region in replication and translation of hepatitis $\mathrm{C}$ virus RNA. J Virol; 77, 3312-3318. 2003.

13. J. Fernandez; D. Taylor; D. R. Morhardt; K. Mihalik; M. Puig; C. M. Rice; S. M. Feinstone; M. E. Major. Long-term persistence of infection in chimpanzees inoculated with an infectious hepatitis $\mathrm{C}$ virus clone is associated with a decrease in the viral amino acid substitution rate and low levels of heterogeneity. J Virol; 78, 9782-9789. 2004.

14. J. P. Monjardino; J. A. Saldanha. Delta hepatitis. The disease and the virus. Br Med Bull; 46(2): 399 407. 1990.

15. M. M. C. Lai, "Hepatitis Delta virus. In: Encyclopedia of Virology (Webster RG, Granoff 
A, editors), London: Academic Press Ltd, pp. 574580, 1994.

16. M. Rizzetto, B. Hoyer, M. G. Canese, J. W. K. Shih, R. H. Purcell, J. L. Gerin, "Delta agent: association of delta antigen with hepatitis B surface antigen and RNA in serum of delta-infected chimpanzees, Proc Natl Acad Sci USA, vol. 77, pp. 6124-6128, 1980.

17. T. I. Huo; J. C. Wu; S. I. Wu; A. L. Chang; S. K. Lin; C. H. Pan; Y. H. Huang; F. Y. Chang; S. D. Lee. Changing seroepidemiology of hepatitis B, C, and $\mathrm{D}$ virus infections in high-risk populations. $J$ Med Virology; 72: 41-45. 2003.

18. M. C. C. Lai. The molecular biology of hepatitis Delta virus. Annual Review of Biochemistry; 64:259-286. 1995.

19. J. M. Taylor. Hepatitis Delta virus and its replication. In: Fields Virology (Fields B.N, Knipe D.M, Howley P.M, editors), 3rd edn. Philadelphia: Lippincott-Raven; pp. 2809-2818. 1996.

20. R. H. Purcell; J. L. Gerin. Hepatitis Delta virus. In: Knipe D. M; Howley P. M; and editors. Fields Virology. $3^{\text {th }}$ edition. Philadelphia: Lippincott Williams and Wilkins; pp. 2819-2829. 1996.

21. T. N. Williams; B. Wonke; S. M. Donohue. A study of hepatitis B and C prevalence and liver function in multiply transfused thalassemic and their parents. Indian Pediatrics; 29(9):1119-24. 1992.

22. M. Montalembert; R. Cirot. Infections In Thalasscmie Patients (Hepatitis And Bone Marrow Transplantation Related Infections Excluded). Prog. Clin. Biol. Res; 309:231-238. 1989.

23. G. B. Schreiber; M. P. Busch; S. H. Kleinman; J. J. Korelitz. The risk of transfusion-transmitted viral infections. The Retrovirus Epidemiology Donor Study. N Engl J Med; 334(26):1685-90. 1996.

24. S. Khalil; H. S. Khan; P. Akhtar. Status of Hepatitis $\mathrm{B}$ and $\mathrm{C}$ in Beta Thalassemia Major Patients. Journal of Islamabad Medical \& Dental College (JIMDC); 5 (2): 71-73. 2016.

25. E. Angelucci; F. Pilo. Treatment of hepatitis C in patients with thalassemia. Haematologica; 93 (8): 1121-1123. 2008.

26. M. M. Ansar; A. Kooloobandi. Prevalence of hepatitis $\mathrm{C}$ virus infection in thalassemia and haemodialysis patients in north Iran-Rasht. J Viral Hepat; 9(5):390-2. 2002.

27. G. Sirchia.; A. Bellobuono; A. Giovanetti and M. Marconi. Antibodies To Hepatitis C Virus In Italian Blood Donors. Lancet; 11:797. 1989.

28. P. Triadou; A. Regnat-Lusinciii; R. Cirot. Use of Ferritin/Alanine Aspartate Transaminase Ratio As An Iron Overload Marker Independent Of Liver
Cell Damage. Europ.J. I [Acmatol.], 43:423-427. 1989.

29. M. A. F. El-Hazmi; and S. Ramia. Frequencies of Hepatitis B, Delta and Human Immune Deficiency Virus Markers in Multitransfused Saudi Patients with Thalassemia and Sickle-Cell Disease. J. Trop. Med. Hyg; 92:1-5. 1989.

30. C. Politis. Complications of blood transfusion in thalassemia. Prog. Clin. Biol. Res.; 309:67-76. 1989.

31. D. T. Covas; E. B. Neto; M. A. Zago. The frequency of blood-borne viral infections in a population of multitransfused Brazilian patients. Rev. Inst. Med. Trop. Sao Paulo; 35 (3): 271-273. 1993.

32. D. Prati; A. Zanella; E. Farma. A multicenter prospective study on the risk of acquiring liver disease in anti-hepatitis $\mathrm{C}$ virus negative patients affected from homozygous beta-thalassemia. Blood; 92:3460-3464. 1998

33. K. Q. Hu. Occult hepatitis B virus infection and its clinical implications. J. Viral Hepatitis; 9: 243-257. 2002.

34. S. Miemomen; S. M. Alavian; B. Hajarizadeh; J. Kafaee; B. Yektaparast. Epidemiology of hepatitis $\mathrm{B}$, hepatitis $\mathrm{C}$ and human immunodeficiency virus infections in patients with beta-thalassemia in Iran: A multicenter study. Arch. Iran Med.; 9: 319-323. 2006.

35. J. P. Allain. Occult hepatitis B virus infection: Implications in transfusion. Vox Sang, 86: 83-91. 2004.

36. J. A. Marero; A. S. Lok. Occult hepatitis B virus infection in patients with hepatocellular carcinoma: Innocent bystander, cofactor, or culprit? Gastroenterology; 126: 347-350. 2004.

37. H. Toyoda; K. Hayashi; Y. Murakami; T. Honda; Y. Katano. Prevalence and clinical implications of occult hepatitis B viral infection in hemophilia patients in Japan. J. Med. Virology; 73: 195-199. 2004.

38. A. Tamaddoni; I. Mohammadzadeh; O. Ziaei. Seroprevalence of HCV Antibody among Patients with $\beta$-Thalassemia Major in Amirkola Thalassemia Center, Iran. Iran J Allergy Asthma Immunol March; 6(1): 41-43. 2007.

39. M. Costello; I. M. Sabatini; M. Yungbluth. Viral infections. In: "Clinical Diagnosis and Management by Laboratory Methods. (McPherson RA, Pincus MR, eds)". Henry's 22nd ed. Philadelphia, PA: Elsevier Saunders, 2011.

40. M. D. Khaled. Prevalence of hepatitis B, hepatitis C and human immunodeficiency virus infections among thalassemia patients in Nineveh 
governorate, Iraq. Egypt. J. Exp. Biol. (Zool.), 10(1): 85-87. 2014.

41. U. Saeed; Y. Waheed; M. Ashraf; U. Waheed; S. Anjum and M. Sohail. Estimation of hepatitis B Virus, hepatitis c Virus, and different clinical Parameters in the Thalassemic Population of capital Twin cities of Pakistan. Virology: Research and Treatment; 6: 11-16. 2015.

42. S. Khalil; H. S. Khan; P. Akhtar. Status of Hepatitis $\mathrm{B}$ and $\mathrm{C}$ in Beta Thalassemia Major Patients. Journal of Islamabad Medical \& Dental College (JIMDC); 5 (2): 71-73. 2016.

43. S. A. Hama. Hepatitis C seropositivity and RNA detection among Type2 Diabetic patients in Sulaimani Governorate- Iraqi Kurdistan Region. Journal of Zankoy Sulaimani-A-.18-4; 1-8. 2016 